\title{
A NEW NOTOSPIRIFERINE GENUS (SPIRIFERIDA: BRACHIOPODA) FROM THE PERMIAN OF TASMANIA
}

\author{
by M.J. Clarke
}

(with one text-figure and one plate)

\begin{abstract}
CLARKE, M.J., 1992 (31:x): A new notospiriferine genus (Spiriferida: Brachiopoda) from the Permian of Tasmania. Pap. Proc. R. Soc. Tasm. 126: 73-76. https://doi.org/10.26749/rstpp.126.73 ISSN 0080-4703. Geological Survey of Tasmania, PO Box 56, Rosny Park, Tasmania, Australia 7018.

Farmerella exoporosa gen. et sp.nov. is described from cold-water Permian (Bernacchian-Lymingtonian) rocks of Tasmania. The new taxon is essentially homeomorphic with Glendonia McClung \& Armstrong, 1978. However, Glendonia possesses a micro-ornament of low, elongate microspines behind shallow, elongate grooves, whereas Farmerella gen.nov. (as in Notospirifer Harrington, 1955) has deep, elongate and globose pits which penetrate the rhickened outer primary shell layer but not the inner shell layer. This feature suggests that Notospirifer and Farmerella gen.nov. are closely related and should be assigned to a separate subfamily, the Notospiriferinae Archbold \& Thomas, 1986 (emended herein), and Glendonia, BirchsellaClarke, 1987 and Kelsovia Clarke, 1990 to a separate subfamily, the Glendoniinae nov. The areal and stratigraphical distributions, and evolutionary relationships of the various genera are briefly discussed.
\end{abstract}

Key Words: Permian, cold-water, spiriferid brachiopod, new taxon, Tasmania.

\section{INTRODUCTION}

Spirifer darwini Morris, 1845, the type species of Notospirifer Harrington, 1955 and Spirifer (Brachythyris) duodecimcostata M'Coy, 1847, both from the Permian Muree Sandstone at Glendon, New South Wales (Armstrong 1969), are two of the earliest fossil taxa described from Australia. Both species are small- to medium-sized spiriferids with short hingelines, rounded cardinal extremities, well-developed fastigia and sulci, and prominent lateral plications. In Notospiriferdarwini the lateral plications are low and rounded, the sulcus is bald, and the fastigium is flattened or bears a shallow median groove, whereas in $S$. duodecimcostata the lateral plications are more acute and subangular, and both the fastigium and sulcus bear a strong median plication. Dorsal adminicula are present in S. duodecimcostata but absent in $N$. darwini. Furthermore, the micro-ornament of $S$. duodecimcostata consists of low, elongate microspines behind shallow, elongate grooves, whereas that of $N$. darwini consists of tiny upright microspines behind short grooves leading anteriorly into deep, globose and elongated pits, which penetrate the thickened outer primary shell layer but not the inner shell layer (Armstrong 1970). For these reasons, S. duodecimcostata and related species have been referred to a separate genus, Glendonia McClung \& Armstrong, 1978. Birchsella Clarke, 1987 and Kelsovia Clarke, 1990 are two related genera, which are externally homeomorphic with Notospirifer in gross shell morphology but differ in internal details and possess low, elongate microspines behind shallow, elongate grooves, as in Glendonia. Farmerella gen.nov. is introduced herein to embrace those forms which are essentially homeomorphic with Glendonia in gross external and internal morphology, but possess deep, globose pits in the thickened outer primary shell layer as in Notospirifer.

The fundamental differences in micro-ornament and shell structure between Notospirifer and Farmerella, on the one hand, and Glendonia, Kelsovia and Birchsella, on the other, suggest that the two groups should be assigned to separate subfamilies, the Notospiriferinae Archbold \& Thomas, 1986 (emended herein) and Glendoniinae nov. respectively.

All five genera occur in Tasmania, which appears to be the principal colonisation area; three genera occur in
Queensland, and two in New South Wales and New Zealand. They are unknown outside the eastern Australian and New Zealand (Austrazean) Province of the Gondwanan Realm.

\section{SYSTEMATIC PALAEONTOLOGY}

\author{
Phylum BRACHIOPODA Dumeril, 1806 \\ Class ARTICULATA Huxley, 1869 \\ Order SPIRIFERIDA Waagen, 1883
}

Family INGELARELLIDAE Campbell, 1959

Subfamily NOTOSPIRIFERINAE Archbold \& Thomas,

1986 (emended herein)

\section{Diagnosis}

Small- to medium-sized shells; hingeline short, cardinal extremities rounded; fastigium and sulcus well developed, sometimes with a strong median plication; lateral slopes with well-marked, broadly rounded or more pronounced subangular plications; ventral interiors with dental plates and supporting adminicula, and little or no posterolateral secondary thickening; dorsal interiors with striate cardinal process, with or without adminicula (tabellae); shell surface with minute suberect microspines behind very short surface grooves leading anteriorly into deep, elongate and globose pits, which penetrate the thickened outer primary shell layer but do not penetrate to the valve interior. The only known genera are Notospirifer and Farmerella gen.nov.

\section{Genus Farmerella nov.}

Etymology

After the late DrN. Farmer, in recognition of his outstanding contribution to the understanding of the stratigraphy of Tasmanian Late Palaeozoic rocks.

Type species

Farmerella exoporosa sp.nov. 

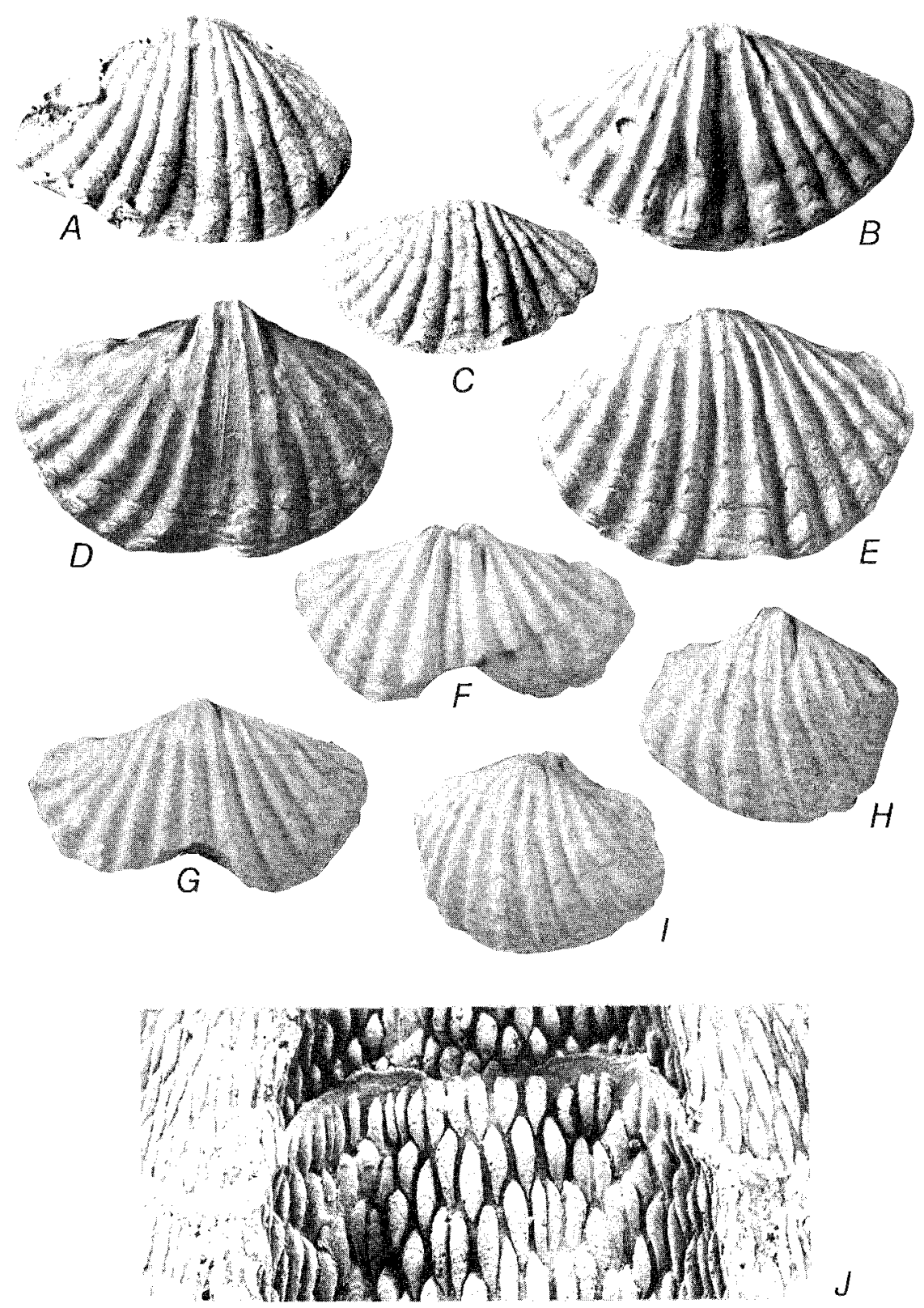

PLATE 1

Farmerella exoporosa gen. et sp.nov. (A) Latex cast of ventral valve exterior GST 15501. (B) Ventral valve internal mould GST 15502. (C) Latex cast of dorsal valve exterior GST 15503. (D-E) Ventral and dorsal views of complete internal mould GST 15504. (F-G) Ventral and dorsal views of complete internal mould GST 15500. (H-I) Ventral and dorsal views of complete internal mould GST 15505. (J) External mould of dorsal valve showing the deep pits in relief GST 15506. GST 15500 is the holotype, all other specimens are paratypes. All figures are natural size except $\mathrm{J}$, which is $\times 20$.

Diagnosis

Forms essentially homeomorphic both externally and internally with Glendonia, but with tiny blunt microspines behind short surface grooves which lead anteriorly in to deep, globose pits in the thickened outer primary shell layer.

\section{Farmerella exoporosa sp.nov. (pl. 1A-J)}

1985 Notospirifer sp.nov. (coarsely plicate species), Clarke (Farmer 1985: 35).

1991 Gen.nov. B, Clarke (1991: 64-65, fig. 5).
Material

Holotype GST $15500 \mathrm{~A}-\mathrm{B}$, a complete internal mould and part counterpart external mould; paratypes GST 15501-10, various complete and incomplete internal moulds and incomplete external moulds; also over twenty other specimens, all from the lower part (early Middle Lymingtonian-Tomiopsis brevis Zone) of the Deep Bay Formation (Unit 30D, Farmer 1985: 101) at EN083152, Deep Bay, Cygnet. GST 15511 A-B, complete internal mould and part external mould, from Deep Bay Formation, South Bruny Island at EN222022, and GST 15512 A-B, complete internal mould and part external mould, from Poatina Group temporarily exposed in Hydro Electric 
Commission Fisher Tunnel, Fisher River area at DP442867. Specimens from a lower stratigraphical interval (Early Bernacchian) are known from the lower part of the Hickman Formation, Harts Hill, Margate at EN203342, and the Rays Hills Arkose (Walker 1957), Cheeseberry Hill, near St Marys, northeastern Tasmania at EQ997004.

\section{Description}

Shell small- to medium-sized, biconvex, of rypical spiriferid form but with subrounded cardinal extremities; hingeline short, considerably less than maximum shell width; fastigium and sulcus well developed, each with a pronounced median plication; flanks of both valves with up to seven coarse, subangular plications on each side; ventral interior with welldeveloped dental plates and supporting adminicula, with little or no posterolateral secondary thickening; dorsal interior with striate cardinal process and short, but well-developed adminicula or tabellae, which are about one-fifth to onesixth of the length of the valve; outer primary shell layers much thickened, with tiny, blunt microspines behind short surface grooves which lead anteriorly into deep, globose pits.

\section{Remarks}

Farmerella exoporosa and Glendonia duodecimcostata are two remarkable, homeomorphic forms, which differ only in their surface micro-ornament and fundamentally distinct shell micro-structure. The latter character in Farmerella indicates a close relationship with Notospirifer. The adminicula show some variation in their development. In the holotype (pl. $1 \mathrm{~F}-\mathrm{G}$ ), and in most specimens they occur between the first and second lateral plications. In others (pl. 1D-E, H-I) they occur between the second and third lateral plications, and in another (pl. 1B) they occur along the crest of the second lateral plications.

\section{Occurrence}

Farmerella exoporosa is relatively common at the type locality and from similar stratigraphical intervals (early Middle Lymingtonian-Tomiopsis brevisZone), Deep Bay Formation, northwest of Poverty Point, Cygnet at EN038149, and South Bruny Island. Rare specimens were collected from temporary exposures of the Poatina Group in the Hydro Electric Commission Fisher Tunnel (Clarke \& Farmer 1973). It is also known from the lower part of the Hickman Formation at Harts Hill, near Margate (Farmer 1985) in beds of Early Bernacchian (Tomiopsis branxtonensis Zone) age, and from beds of a similar or slightly younger age at Cheeseberry Hill, near St Marys, northeastern Tasmania.

\section{Subfamily GLENDONIINAE nov.}

\section{Diagnosis}

As for Notospiriferinae, but shell surface with low, elongate microspines behind shallow, elongate grooves; thickened outer primary shell layer with deep, globose pits absent. Dorsal valveadminicula are present in Glendonia and Kelsovia but absent in Birchsella, which also has very heavy posterolateral secondary thickening in the ventral valve.

\section{DERIVATION AND DISTRIBUTION}

All five genera may have been derived from the genus Tomiopsis Benediktova, 1956, which occurs abundantly



FIG. 1 - Inferred ingelarellid phylogeny and stratigraphical distributions within Tasmania.

throughout the Permian of eastern Australia and New Zealand, by a process of change in shell form, variable modification of the micro-ornament and variable loss of the dorsal adminicula (fig. 1).

Kelsovia is the oldest known genus which makes its appearance in Late Tamarian (Asselian) rocks in Tasmania with the type species Kelsovia superba. Younger species include Notospirifer undulatus Parfrey, 1986 and Notospirifer? sp.nov. McClung \& Armstrong, 1978, both from Queensland, and Kelsovia sp.nov. from the Kazanian of Tasmania. It is unknown in New South Wales and New Zealand.

Notospirifer probably derived independently from a parent Tomiopsis, whereby the primary shell layer is thickened and the shallow, elongate, cigar-shaped grooves of Tomiopsis develop into deep, globose pits. The oldest species, Notospirifer sp.nov. from the Tastubian of Tasmania, has dorsal adminicula, but in all younger species they are absent. Notospirifer sp.nov. appears to be the true ancestral Notospirifer, in that some specimens show the repeated progressive modification of a Tomiopsis micro-ornament into a Notospirifer micro-ornament on successive major growth increments. Notospirifer is widely distributed throughout the Permian sequence of eastern Australia and occurs in rocks as young as Kazanian in Tasmania, New South Wales and Queensland.

Species of so-called Notospirifer from New Zealand (Waterhouse 1964 et seq.) need to be reassessed. Waterhouse (1967) appeared to confuse the two Glendon species 
Notospirifer damini (Morris) and Glendonia duodecimcostata (M'Coy). The micro-ornament said to characterise Notospirifer by Waterhouse (1967) belongs with Glendonia (Armstrong 1969, McClung \& Armstrong 1978, Clarke 1987). Nevertheless, N. macropustulosus Waterhouse 1968 is a true Notospirifer, whereas the holotype, at least, of N. mirrostriatus Waterhouse 1964 belongs in Glendonia (Campbell \& Clarke, in prep).

Farmerella, which only occurs in Tastubian-Aktastinian rocks in Tasmania, may be derived from Notospirifer by an increase in the strength of the lateral plications and the development of a strong median plication in both the fastigi um and sulcus. More probably it derived independently from a Tomiopsis ancestor, since dorsal adminicula are retained

Birchsella is known only from Kazanian rocks in Tasmania, and appears to be a later derivative of Kelsovia, whereby the dorsal adminicula atrophy and the ventral valve develops heavy posterolateral secondary thickening.

Glendonia, which occurs widely in Tasmania, New South Wales and Queensland in Aktastinian-Kazanian rocks, is probably derived from Kelsovia by an increase in the strength of the lateral plications and the development of a strong median plication in both the fastigium and sulcus. Dorsal adminicula are retained, as in the ancestral Kelsovia (and Tomiopsis).

\section{ACKNOWLEDGEMENTS}

I thank E.L. Martin and W. Jablonski for taking the photographs and E. Williams and S.M. Forsyth for critically reading the manuscript which was typed by Anne Taylor. H.J. Campbell kindly provided access to some New Zealand material. The author publishes with the permission of the Geological Survey of Tasmania.

\section{REFERENCES}

Archbold, N.W. \& Thomas, G.A., 1986: Permian Ingelarellidae (Brachiopoda) from Western Australia and Argentina. J. Paleont. 60(3): 581-605.

Armstrong, J.D., 1969: The martiniacean species occurring at Glendon, New South Wales, the type locality of Notospirifer darwini (Morris). J. Proc, R. Soc. NSW 101: 197-204.

ARMstrong, J.D., 1970: Micro-ornaments of the spiriferid brachiopods Notospirifer, Ingelarella and Subansiria. Lethaia 3: $287-300$.
BenfidikTOVA, R.N., 1956: Spiriferidy Ostrogskoi svity Kuzbassa. Voprosy Geologii Kuzbassa, Materialy vtorogo soveschinya po stratigrafi uglenosnykh otlozhenii 1: 169-182.

Campbel.L., K.S.W., 1959: The Martiniopsis-like spiriferids of the Queensland Permian. Palacontology 1: 333-350.

Campbei.l., H.J. \& Clakke, M.J., in prep. A revision of New Zealand Notospirifer and related forms.

Clarke, M.J., 1987: Late Permian (late Lymingtonian = ?Kazanian) brachiopods from Tasmania. Akheringa 11: 261-289.

Ciarke, M.J., 1990: Late Palaeozoic (Tamarian; Late CarboniferousEarly Permian) cold-water brachiopods from Tasmania. Alcheringa 14: 53-76.

Ciarke, M.J., 1991: Notospirifer Harrington, 1955 and related spiriferid genera from the Permian of eastern Australia and New Zealand. In Mackinnon, D.1., Campbell, J.D. \& Lee, D.E. (Eds): BRACHIOPODS THROUGH TIME. Proc. 2nd Int. Brachiopod Congr., Dunedin, New Zealand 1990. Balkena, Rotterdam: 63-66.

Clarke, M.J. \& Farmer, N., 1973: The Fisher Tunnel Permian section and its relation to the Kansas Creek section, Tasmania. Tasm. Dep. Mines Tech. Rep. 16: 41-49.

Farmer, N., 1985: Kingborough, Tasmania. Tasm. Dep. Mines 1:50 000 Geol. Atlas Ser., Explan. Rep., Sheet 88

Harrington, H.J., 1955: The Permian Eurydesma fauna of eastern Argentina. J.Paleont. 29: 112-128.

McClung, G. \& Armstrong, J.D., 1978: Species of Glendonia (Ingelarellinae-Spiriferida) in the Permian of eastern Australia. Palazont. Pap No. 39, Geol. Surv. Qld Pub. 365: $1-5$.

M'Coy, F., 1847: On the fossil botany and zoology associated with the coal of Australia. Ann. Mag. Nat. Hist. 20: 145-157, 226-236, 298-312.

MorkIs, J., in Strzelecki, P.E. de, 1845: PHYSICAL DESCRIPTION OF NEW SOUTH WALES AND VAN DIEMENS LAND. Longman, Brown, Green and Longman, London: 270291.

Parfrey, S.M., 1986: Early Permian invertebrates from the Camboon Andesite near Bileola, southeastern Bowen Basin. Geol. Surv. Qld Pub. 387: 57-67.

WAiker, K.R., 1957: Geology of the St Helens-Scamander Area. Pap. Proc. R. Soc. Tasm. 91: 109-114.

Waterhouse, J.B., 1964: Permian brachiopods of New Zealand. New Zealand Geol. Surv. Paleont. Bull. 35: 1-287.

WA'TERHOUSE, J.B., 1967: The ornament of the Permian brachiopod Notospirifer Harrington, 1955. J. Geol. Soc. Aust. 14: 273280.

Waterhouse, J.B., 1968: The classification and descriptions of Permian Spiriferida (Brachiopoda) from New Zealand. Palaeontographica A129: 1-94.

Waterhouse, J.B., 1982: New Zealand Permian brachiopod systematics, zonation and paleoecology. New Zealand Geol. Surv. Paleont. Bull. 48: 1158.

(accepted 6 December 1991) 